\title{
JSB as Democratic Emblem and Urban Focal Point: The Imagined Socio-Political Construction of Space
}

\author{
*Bayezid Ismail Choudhury, Peter Armstrong, Paul Jones \\ University of Sydney, Australia \\ *bcho0140@usyd.edu.au
}

\begin{abstract}
Jatio Sangsad Bhaban [JSB], more commonly known as the National Assembly Building, or Capital Complex of Bangladesh, was designed by the renowned architect Louis I. Kahn and is an iconic landmark in the urban landscape of Dhaka (Capital of Bangladesh). It was commissioned in 1962, and a site was selected on the northern outskirt of the then Dacca (Dhaka). From the inception of the city, the rapid growth occurred mostly in a spontaneous way, which later occurred surrounding the JSB. JSB has become a central physical focus in Dhaka because of organic growth of Dhaka. JSB, the national assembly building of Bangladesh, can be viewed as a product of Bangladeshi nationalism, a socio-political construct that expresses both the national identity and the democratic spirit of the Bengali people after the country's tumultuous history of subjugation, occupation. This paper proposes that there exists an imagined, symbolic and metaphorical connection between the spatial construction of JSB as an urban focal point, and its socio-political construction. This imagined nexus is explored in this paper in line with the theoretical framework of Lefebvre's (1991) groundbreaking treatise on the 'production of space'. The imagined and real socio-political construction of space is also endorsed by a range of discourses from urban anthropology, urban geography, human and cultural geography.
\end{abstract}

Keywords: Jatio Sangsad Bhaban, Urban focal point, Louis I Kahn, Dhaka, Capital Complex

\section{Introduction}

JSB, or National Assembly Building, in Dhaka, Bangladesh, is an epic building designed by renowned American architect Louis I Kahn. The literature suggests that, after the Capitol Complex of Chandigarh, designed by Le Corbusier, it is the most significant work of modern architecture in Asia (Ashraf, 1994).JSB or Capitol complex is not only significant in terms of its architectural merit, but also is now regarded as national emblem of democratic Bangladesh ${ }^{1}$. It emerged as this after a long history of drama and paradox (Choudhury, Bell, 2011). It was commissioned in 1962 by the military dictator of West Pakistan, Ayub Khan, mainly to fulfil his political agenda concerning East Pakistan, which later became independent Bangladesh. After twenty-one years had been spent on the commissioning process JSB was finally completed in 1983 as an architectural marvel of the world, with its picturesque surroundings in almost 1000 acres of land (Choudhury, Armstrong, 2012). It bears testimony to Bangladesh's history, having witnessed the political struggle of East Pakistan against West Pakistan that culminated in the war of independence in 1971. It also witnessed the extreme misuse of power by the power-hungry nationalist and military forces of independent Bangladesh. Nonetheless, it emerged as a symbol of national identity from 1991 after almost twenty years of independence, when a truly democratic electoral system was introduced in Bangladesh. Thus, it retained its strength as a democratic emblem because of socio-political processes.

JSB was originally located on the northern outskirts of Dacca (Now Dhaka).Because it was planned that it would be the second capital of Pakistan a vast area of farmland was acquired to build citadel of Assembly, comprising the main assembly building and citadel of Institution comprising institutional buildings (Choudhury, Armstrong, 2012). Finally, the Citadel of Assembly was built. The JSB complex, originally intended to be an independent city, had, by the time it was completed, instead became the focus of the vibrant megacity of Dhaka, having grown in an almost spontaneous manner. All top down, apparently undemocratic

${ }^{1}$ Bangladesh (Formerly East Pakistan) earned its independence from Pakistan in 1971. When the British departed the Indian subcontinent in 1947 they divided India into three parts, comprising West Pakistan, India and East Pakistan, mainly based on religious affiliations of the residents. The area inhabited by the Muslim majority became Pakistan (East and West), and the rest remained as India. 
master plans and regulatory controls during the British and Pakistani colonial periods failed to regulate the shape Dhaka took as it grew. Post-independence top down regulatory controls, which mainly followed the colonial system of planning, also failed meet the demands of a city that was thriving on organic growth. The JSB complex has unintentionally and spontaneously become the urban focal point of Dhaka and today can be perceived as a product of spatial construct. The conceptual aim of this paper is to construct a nexus between the social construction of JSB as a democratic emblem and its spatial construction as an urban focal point, principally in line with Lefebvre's theoretical framework of 'production of space'. The imagined and real social construction of space is widely accepted and a topical phenomenon especially in the social, cultural and geographical discourse on cities. Tonkiss contends that the socio-political milieu of urban society can be connected to complex urban symbolic forms as a palimpsest of socio-political forces (2005). Castell (1978) and Geddins (1979) visualise urban built forms as repositories of socio-political history and cultural meanings of people. Bounds argue in this regard, 'The city is part of the wider society, with socio-political processes amenable to urban analysis. It is an area in which the structure and process of society can be studied' (2004, p 43).

To many scholars the spatial aspect of the city is a representation of the values, customs, and way of life of city people (Low, 2004, Castell 1977, Amin, Thrift 2002). This paper will attempt to explore the link between the form JSB has assumed as the urban focal point of Dhaka and its symbolic connection with the long process of societal transformation that has led to its social construct as a democratic entity. Our concern is to look at the spatial construct of JSB, the urban focal point as an imagined product of its social construct, rather than the opposite. Our stand is in line with Rotenberg's statement, 'urban space is the product of rather than producer of social effects' $(2001, \mathrm{p} .8)$. However, some scholars argue that both social construct and spatial construct are mutually dependent. Wright puts the case that both built environment and society are formative and mutually configure each other (1988). Tonkiss' argument supports such a mutual relationship: 'Urban spaces can be seen as structuring social relations and processes, and in turn as shaped by social action and meaning' (2005, p.2). The paper proposes the configuration of JSB as an urban focal point to be a parallel corollary of the democratic status of Bangladesh. An extensive literature relating to such conceptualisation of urban areas has evolved (Low, 2004; Castell 1977; Amin, Thrift 2002). Envisaging a city, and its role as a democratic space, is both desirable and critically important, especially in relation to its geo-historical transformations (Low, 2004). Low states, 'cities are certainly spaces where democracy should matter, work, be tested and extended, even if they are not in some way spatially or socially fundamental in our thinking about this form of rule' (2004, p.145).

Social Construction of Space - Real and Imagined: The dynamics of the relationship between society and space are unambivalent, although there is no specific approach to their multifarious workings. The societal and spatial constructs are in some instances direct and mutual, and sometimes symbolic and metaphorical, as is the case in our discussion. These social constructs of space encompass social, economic, ideological, and technical dimensions, whose intended goal is the physical creation of space. Wright (1988) contends that both the spatial and societal constructs are mutually formative, although the two domains cannot be linked through any standard approach. Susser's (2002) analysis of the social construction of space best matches our approach to understanding the transformation of Dhaka's political scenario from one of turbulence to elective democracy: 'Spatial transformation must be understood in the broader context of social transformation: space does not reflect society, it expresses it, it is a fundamental dimension of society, inseparable from the overall process of social organisation and social change' (2002, p.393). The connection drawn in this paper between the democratic status and the function of urban focal point of JSB partakes of the symbolic, the metaphorical and the imagined. Such an imagined link between society and other discourses is a widely accepted norm in the treatise of the built environment and the creative arts, such as language and visual arts (Lawrence, Low, 1990). With regard to the built environment Lawrence and Low argue, 'Theories of metaphor have been used by a number of anthropologists to explore architecture and the built environment as a symbolically encoded cultural meaning system'. (190, p. 472).

\section{Theoretical Framework: The Socio-Political Construction of Space}

The symbolic association of Bangladesh's social and political upheaval and transformation to democratic status, with the nation's growing urban focus as epitomized by JSB is complex. However, the theory best 
suited to our case has been extrapolated from Henry Lefebvre's theory of the 'treatment of space as social product.'2 This theory operates on three levels. The third level, 'Representational Space', is a good fit for our case. Lefebvre delineates this kind of space as 'embodying complex symbolisms, sometimes coded, sometimes not' (1991). Tonkiss argues in relation to this third level of Lefebvre's space that 'representational spaces are spaces of imagination, embodiment and desire. They are tied to symbolic and artistic practices.' (2005, p.3). That is, he argues that Lefebvre's representational space can be experienced in varied ways, through the symbolic understanding of context, that conform to our argument. The perceived urban focus of JSB as a social construct is in essence a theoretical exploration. Lefebvre argues in regard to social space, 'Every social space is the outcome of a process with many aspects and many contributing currents, signifying and nonsignifying, perceived and directly experienced, practical and theoretical' (1991, p.110). The social construction of space in this paper broadly falls into the categories of 'perceived' and 'theoretical'. Gottdiener contends in relation to Lefebvre's social space that 'space is both the geographical site of action and the social possibility for engaging in action' (1985, p.123). Our discussion has a particular geographical dimension that is enriched by a socio-political understanding. Apart from Lefebvre's theory of the production of space, our article is also supported by a number of cross-disciplinary discourses. The imagined and actual link between social change and the dynamic spatial articulation and restructuring of the urban environment is a discourse of urban geography, urban sociology, cultural geography and allied fields (Wyly 1999; Harris 1995; Tonkiss, 2005).

\section{The Social Construction of JSB as Democratic Emblem}

Although significant for its physical quality as an architectural masterpiece, JSB is inherently a socio-political construct. It has forged a national identity for the people of Bangladesh (Choudhury, Armstrong, 2012). It evolved as a dynamic force in the internal political interplay between East and West Pakistan. This construct spans two historical periods, those of pre- and post-independent Bangladesh.

Pre-independence Social Construction of JSB: JSB is ostensibly a product of nationalism. The idea of JSB originated with a dictator from West Pakistan mainly to appease the people of Bangladesh (formerly East Pakistan) (Choudhury, Bell, 2011). In order to fully comprehend the pre-independence setting it is important to articulate the tumultuous political discord between Bangladesh (then East Pakistan) and West Pakistan. Pakistan emerged as an independent country in August 1947 whose east and west was in congenital conflict (Mascarenhas, 1971). East and West Pakistan are segregated in all aspects of life other than religion (Schuman, 1972).Four major grievances undermined the sovereignty of East Pakistan: a lack of participation in decision-making processes; the refusal to recognise Bangla as the national language (of East Bangladesh); and excruciating economic disparities (Choudhury, Bell , 2011; Mascarenhas, 1971).The economic disparity was utterly intolerable in a setting where the east contributed significantly to the national exchequer (Choudhury, Bell , 2011; Mascarenhas, 1971). Moreover, there was a huge trade deficit, Bangladesh taking $80 \%$ of West Pakistan's exports while West Pakistan imported only 20\% of Bangladesh's output (Mascarenhas, 1971). It was against this backdrop that General Ayub Khan took control of Pakistan. Ayub, a graduate of Sandhurst Military Academy, was sympathetic to East Pakistan and initiated many development schemes for the region, including a significant increase in public sector expenditure (Talbot, 1998). He reasoned that such a measure would help him win the hearts and minds of the Bengalis (Choudhury Bell, 2011; Ksiazek, 1993). However, the people of East Pakistan were not appeased by the proposal to build the House of Assembly in Dhaka (Ksiazek, 1993, Choudhury, Bell, 2011). As Schendel observed, 'The military regime saw itself [JSB] as stern, fair, constructive, efficient and avuncular. Most East Pakistanis, however saw it as autocratic, imperialist, violent and geared to perpetuating the vice-regal power of Ayub Khan' (2009, p. 120). This meant that JSB in the pre-independence period represented a socio-political construct mainly to cater to the caprice of a military dictator.

\footnotetext{
${ }^{2}$ Lefebvre (1991) argues that production of space operates on three levels. The first one, in which space is produced, is an effect of spatial practice. It reflects 'spatial sets characteristic of each social formation.' The second, 'representation of space', ordering conception of space, typifies scientific, architectural and/or governmental ordering of space. He argues that spaces are products of nature. Space evolved from economic, technical political and strategic realms. Our space, JSB, as an urban focal point, can be understood as a production of space as a socio-political construct.
} 
Post-independence Construction of JSB as an Emblem of Democracy: The birth of Bangladesh in 1971 totally changed the regime, and JSB ${ }^{3}$ emerged as a true democratic emblem after 1991. In the period from 1971 to 1991 the nation was ruled, and suppressed, by extremist nationalist force, under turncoat politicians and military dictators. Independence, granted on December 16, 1971, imbued the people of Bangladesh with fresh hopes and aspirations. The devastated nation faced challenges as well as opportunities. After the groundbreaking task of formulating a new constitution, based on the four pillars of nationalism, democracy, socialism and secularism, was achieved in 1972, under the leadership of Sheikh Mujibur Rahman, the nation was paradoxically delivered to autocratic rule by the same person (Baxter, 1998). Sheikh Mujib's reign as dictator did not last long, as he soon fell victim to a military coup (Baxter, 1998). After a brief and turbulent interval Ziaur Rahman, a soldier-turned-politician, assumed the leadership of Bangladesh on November 7, 1975, after a soldiers' mutiny. After assuming the presidency in April 1977 Ziaur amended the constitution (Jahan, 2005). Thus, the constitution had been repeatedly violated in order to achieve personal political benefit. Ziaur Rahman was assassinated by army officers on May 30, 1981 (Baxter, 1998).

After a brief period of civil rule Lieutenant General Ershad, the chief of army staff, staged a bloodless coup, took power on March 24, 1982, and suspended the constitution (Baxter, 1998). After almost a decade of dictatorial rule, General Ershad resigned on December 4, 1990, in the face of growing opposition from students and political parties (Baxter, 1998). Ershad's resignation marked a new era in the democracy of Bangladesh and it was then that the true democratic identity of JSB emerged: after Ershad's resignation, a genuine electoral democratic process, which persists, was initiated for the first time in Bangladesh's history. In a connection Jahan wrote, 'Ershad's resignation in the face of nearly eight years of continuous political movement against military rule marked a watershed in Bangladesh's political history. It was perceived as a victory for democracy and constitutional rule.' (2005, p.285). JSB housed its first truly democratic ${ }^{4}$ session in 1991 after the parliamentary election under a caretaker government ${ }^{5}$ on February 27, 1991. From then on JSB was regarded as an emblem of the national identity of Bangladesh and the democratic expression of the Bengali people. Thus after a long political and social upheaval, beginning with independence in 1971, from 1991 on JSB can be seen as a democratic emblem that evolved out of a socio-political construct.

\section{The Spatial Construction of JSB as an Urban Focal Point}

The spatial construct of JSB is a dynamic interaction between two factors: the growth of Dhaka in relation to JSB, and discussion of planning instruments and controls, which regulate the building's growth. About the spatial aspect of planning Faludi points out that planning doctrine is generally a factor of spatial arrangement and development concerning patterns of urbanisation and growth and the regulatory issues encompassing the approach to planning and its institutional regulation (2000). Therefore, the following discussion conflates two aspects of the spatial construction of JSB.

The Growth of Dhaka revolves around JSB: Dhaka is a 'wide-sweeping plain', a fertile area with its origin on the northern side of the River Buriganga, a tributary of the Ganges (Karim, 1964). The historian Dani depicts $17^{\text {th }}$ century Dhaka, 'with its minarets and spacious buildings (as having an) appearance like that of Venice in the west, of a city rising from the surface of water' (1962, p.50). It was a place that grew out of the chemistry between land and water, with its numerous khals (lakes) and pukurs (ponds) providing navigability to all parts of land (Chowdhury, Faruqui, 2009). The pre-Mughal physical history of Dhaka is not recorded and is therefore unknowable (Hossain, 2008; Chowdhury, Faruqui 2009). Sonargaon close to Dhaka and now regarded as a heritage city, enjoyed the status of city during the pre-Mughal Period. Dhaka's importance rose after it was made the capital by Islam Khan Chishti in1610 CE, who named it Jahangirnagar, after a previous Mughal emperor (Chowdhury and Faruqui 2009). At that time, the city grew out of an area of 2.20 sq.km and part of present old Dhaka (Hayder, 1987; Hossain, 2008). This growth continued and Dhaka

\footnotetext{
${ }^{3}$ JSB was completed in 1983

${ }^{4}$ During Ershad's regime there had been two parliamentary elections, in1986 and 1988. But there remained a question over the legitimacy of these elections based on whether Ershad's government itself was a legitimate one (Jahan, 2005). Paradoxically the first session of JSB after its completion was illegitimate.

${ }^{5}$ In 1991 for the first time Bangladesh initiated a non-party, neutral caretaker system, responsible for supervising a fair and neutral election. It was expected that this would help to restore true democracy (Milam, 2009).
} 
had expanded to 17.0 sq km by 1901 (Hossain, 2008). 1905 was a landmark year, when Dhaka gained the status of provincial capital. The new town extended towards Ramna, which had been developed in line with the European garden city concept to cater to the office and residential needs of the government of the newly created province (Chowdhury, Faruqui 2009). During the period from 1905 to 1911, the university area was developed and the colonial authority envisioned Dhaka as a university city following the model of the European University City (Geddes, 1917; Chowdhury, Faruqui, 2009). However, this vision did not materialise and Dhaka grew in an organic manner. The growth of Dhaka reached its highest momentum after the partition of India. Choudhury argues that 'the sudden flow of people to Dhaka in the post-1947 period created the 'new Dhaka' in the highland available north, north-east and north-west of Ramna [the centre of colonial Dhaka]' (Chowdhury, Faruqui 2009, p. 72).

It was in this context of Dhaka's expansion that the selection of a site for JSB - on the northern outskirts of the city - was made in 1962. After an historic conferences of governors, held at Nathiagali on June 12 and 13, 1959, the decision to establish a second capital at Dhaka was proposed. To put this decision into effect a second Capital Committee was set up to designate a location and for other development. The committee, headed by the Governor of East Pakistan, suggested the site at the Tejgaon Agricultural Firm and recommended 200 acres be used for its establishment. The area was considered inadequate and the committee then proposed 1000 acres. There were several reasons for selecting this site, including that it contained about 600 acres of open buildable land, had a suitable altitude (24 to $30 \mathrm{ft}$ above sea level) and could eventually be extended northwards. Its tranquil setting also conforms to the function. One of the most important features of the site was the location of two highways, one on the east (Dhaka Mymanshing Road) and one on the west (Mirpur Road), which would enhance the building's connectivity (file no - $w$ - cap-58/ace collection no -10 , year -1968). By the time JSB had been completed Dhaka had undergone considerable expansion around it. JSB had become the geographical centre of the city. The huge parcel of land preserved for JSB later emerged as the "lungs" of the city. Vale's interpretation of JSB's geographical relationship to its city is somewhat at odds with our perception that the building's function as urban focal point constitutes a parallel to democratic expression. He argues, 'though the city of Dhaka has long since grown northward far enough to encompass Sher-e-Bngla Nagar, its embrace is a cautious one' (2008, p.311). His argument mainly reflects the idea of a segregated city comprising relationships of dominance and subordination that are symbolised by JSB's very monumentality, which sets it apart from the rest of the city. We argue on the other hand that such physical domination of democratic space has historical antecedents in places of democratic assembly ranging from the agoras of ancient Greek cities to present day Boston City Hall Plaza and Pershing Park in Washington; the growth of Dhaka around JSB occurred spontaneously and organically, making it an urban focal point which is equally significant as its role as democratic emblem (fig 1)

Regulatory Issues Impinged on Spatial Construction: Planning regulations, such as land use, development control and environmental plans is inherently a tool for demonstrating power especially that of colonial rulers in colonized countries. The realm of planning is an instrument of politics and power. Findley (2005) contends that colonialism cast its far-flung influence through the introduction of spatial and architectural practices to the colonies. Similar interpretations of planning as a vehicle of control can also be found in discussions by Al Sayyad (1992), Dovey (1999), Njoh (2003; 2007) and Cooper (2000). After taking control of Dhaka the British colonial administration established the Dhaka Municipal Corporation and initiated the Geddes master plan in 1917 in order to control the city's growth (Ahmed, 1986). Njoh (2007) contends that the British colonial authorities employed urban planning policies and projects as vehicles for inculcating the idea of civilising the 'inferior race': the mission civilisatrice. Njoh suggests that this process was used in connection with town planning, observing 'it is true that town planning in British colonial possessions was derived from British town planning legislation, principals and practice' (2007, P.145). That is, from its inception, British governance in Dhaka can be perceived as top-down undemocratic. The colonial planning and regulatory institution was inherently a governing system designed to serve the colonial interest (Gable, 1967). Gable argues, 'the colonisers also had to resort to a system of pseudo-justification, stereotyped behaviours, and discriminatory actions and in turn create social institutions which would reinforce these beliefs and behaviour' (1967, p.476). Due to inherent incompleteness and lack of political vision in the Geddes master plan it mostly failed to progress beyond the paperwork stage (Hayder, 1987). Dhaka grew during British rule along its own lines. 
After the British withdrew in 1947 Pakistan became self-ruling. In planning terms, it was like old wine in new bottles. Nothing significantly changed in terms of attitudes to urban planning from the approach of the colonial ruler. As Glebe wrote, 'with the departure of the British, those trained by the British constituted the group with the continuity to project British values - "an elite within an elite"' (1967, p.478). Moreover, the bureaucratic order being mostly dominated by West Pakistanis marginalised Bengali bureaucrats: as Jahan points out, 'Bengali participation in these three types of central policy-making institutions -commissions of inquiry, the central secretariat, and public corporations - was marginal' (Jahan, 1972, p.98). However, a committee was formed following the 1962 constitution to reorganise the function and structure of the central government. Its report proposed increased East Pakistani participation in government (Jahan, 1972). Although this proposal was implemented the situation was unchanged, with power remaining largely the preserve of the central government (Jahan, 1972). Jahan notes that 'the fact that Ayub had a near monopoly on political power meant that the provincial administration couldn't take any determined and effective stand against the centre's wishes, for it had no political power to support its position' (1972 p.105). Under this discriminatory balance of power several planning instruments and laws were formulated that dictated the development of Dhaka. In 1952 the Building Construction Act was introduced, followed in 1953 by the Town Improvement Act for the development of metropolitan Dhaka, which established the parent organisation for Dhaka, the Dhaka Improvement Trust (Zaman, Lau, 2000). Under the Trust's supervision the Dhaka Master Plan was formulated in $1959^{6}$ by the British firm Minorio, Spancely and Macfarlane. The purpose of this plan was to provide an outline for anticipating the rapid growth of Dhaka with consideration of the population factor (Begum, 2007). At this time the area of Dhaka was 220 square miles, with a population of 575,000 (Macfarlane et. al., 1959). However, like Geddes' master plan, this plan did not gain formal recognition and failed to respond to the need of the city (Hayder, 1987, SENES-TCIL, 2007). In regard to the bureaucratic shortcomings of the 1959 Master Plan Hayder states, 'Thus the future of the city eventually fell into the hands of tyrannical and whimsical decision makers' (1987, p. 98). However, Dhaka maintained its own pace and pattern of growth. Chowdhury and Faruqui argue, 'The development under the aegis of the Dhaka Improvement Trust followed the dictation of nature, rather than dictating nature, to augur a planned growth' ( 2009, p.74 ).Thus, due to spontaneous, almost organic and free flowing growth, (Khan and Nilufer,2009; Nilufer, 2004), Dhaka has become one of the most vibrant cities in Southern Asia. The city's rapid growth after independence saw JSB dramatically transfigured into an urban melting pot, parallelling its democratic status. Commissioned at the periphery of growing Dhaka in the early sixties, JSB became the centre of the city in the mid eighties in a spectacular historical process.

\section{In Retrospect}

Central to our discussion is the imaginative nexus between socio-political upheaval and the assumption of the status of democratic emblem by JSB with the physical transformation of an organically growing city, which turned the building into the urban focal point. Both the social construction of JSB as democratic emblem and its spatial construction as urban focal point are intertwined. We argue that the socio-political domain of the history of Bangladesh engendered the spatial construction of JSB as urban focal point in a symbolic way; that is, that the spatial aspect of JSB is the product of its social construction. The urban focus provided by JSB in this interpretation expresses the historic upheaval and wider struggle of the Bengali people against all oppression and subjugation. Therefore, in highlighting the centrality of this democratic institution to the city of Dhaka this paper will evoke a sense of pride and satisfaction for the Bengali people. Appreciating the historical prestige that suffuses the space of JSB will enhance the sense of belonging of Dhakaites and enable them to perceive it as something more than mere physical space, but as place as well. As Rotengerg asserts, 'People's understandings transform space into place' (1993, p.XII). However, we are aware this romantic association and imaging of JSB may not be shared by all Dhakaites, a large number of whom are hard pressed simply to secure the basics of life. Tonkiss (2005) argues that cities' spatial stories may not be equally shared by all social actors. These stories are fashioned by perception and understanding of individual mental maps.

In establishing the symbolic nexus between the social and spatial constructs of JSB, incorporating a wide range of socio-political and geographical history, this paper is important as a discourse of urban history and

\footnotetext{
${ }^{6}$ On August 26, 1957 the firm was instructed to formulate a plan by the Secretary for Commonwealth Relations for the Dhaka Improvement Trust under the Technical Co-Operation scheme of, the Colombo Plan. It took a year to prepare the working plan.
} 
historiography. Wright points out that 'urban history can show how major buildings and monuments affected the cities around them; creating distinctive styles and urban space' (1988 p.11). Both the Bengali struggle against oppression and subjugation in the socio-political realm, expressed through the democratic spirit encapsulated in JSB, and the spontaneous growth of Dhaka, ignoring top-down autocratic planning, give JSB its character of an urban focal point. This adds a new dimension to the paradigm of urban history in Dhaka. In Sassen's terms, 'the city has long been a strategic site for the exploration of many major subjects confronting society and sociology' (2010, p.3). Therefore, the spontaneous growth of Dhaka that has made JSB an urban focal point, which we perceive as symbolising a social construct, meets the criteria for the essence of an ideal city. Does it do this in line with the contemporary buzzword sustainable city? The answer is both yes and no. The idea of the organic growth of a vibrant city is central to many scholarly arguments. The assumption that JSB is its focal point adds value to Dhaka's organic growth. Alexander states in connection to organic growth, 'When we look at the most beautiful towns and cities of the past, we are always impressed by a feeling that they are somehow organic' (1987, p. 2). Jacob argued for the merit of the complex and diverse growth of a city disregarding any plan (1961). This idea is echoed in Alexander's article City is not a Tree. Alexander argues that 'artificial cities' or 'planned cities' lack some essential components that 'natural' or 'organic' or 'spontaneous' cities possess and which give them their particular interest (Taylor, 1998). Alexander asserts that natural cities are much richer for their complex overlapping relationships (Taylor, 1998). Jacob was critical of the neatly ordered view of the ideal urban structure (1961).

In terms of sustainability the question remains open. A sustainable city in general has to address a multifaceted strategy incorporating socio-economic, environmental and cultural interests (Camagni, Capello, 1998). The link between the social and spatial domains made by JSB may meet the cultural aspiration and value of the nation's society. However, other components are yet to be resolved about Dhaka. Nonetheless, the component of culture as a construction of space is a drawing force for global aspirations (Kong, 2007). Kong points out that 'increasingly, attention has also been given to the cultural production of space and place, often in monumental proportions, as a means of attracting and sustaining global human and economic flows' (2007, p.384). This argument would suggest that the spatial construction of JSB could attract such a "global human and economic flow." In urban design terms is JSB as urban focal point a successful aspect of urban design that evolved within the spontaneous growth of Dhaka? Lang argues that the intrinsic success of an urban design revolves around its vision (2005). The symbolic connection between the spatial and social constructs of JSB constitutes an idealistic vision, thus indeed making it quite a successful urban design within the precinct ${ }^{7}$ of the city. Lynch's statement supports our claim that JSB is a successful and desirable spatial construct: he writes, 'I shall argue that a desirable image [city] is one that celebrates and enlarges the present while making connection with past and future' (1972, p1).



JSB Complex as Urban focal point. (Source: Environ Monit Assess (2009) 150:237-249)

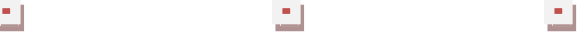

\footnotetext{
${ }^{7}$ Lang argues, 'most urban designs deal with precincts of cities rather than cities as a whole...Brasilia and Changarh fall under this category.'
} 


\section{References}

Ahmed, S. (1986). Dacca: A Study in Urban History and Development. London, Curzon Press Alexander, C. (1987). A New Theory of Urban Design. New York, Oxford University Press.

Amin, A. \& Thirft, N. (2002). Cities: Reimagining the Urban. Cambridge, Polity Press

Ashraf, K. K. (1994). Louis I. Kahn: National Capital of Bangladesh, Dhaka, Bangladesh, 1962-83. Global Architecture, 72, 1-47.

Baxter, C. (1998). Bangladesh: From a Nation to a State. Boulder, Colo., Westview Press.

Begum, A. (2007). Urban Housing as an Issue of Redistribution through Planning? The Case of Dhaka City. Social Policy and Administration, 41(4), 410-418

Camagni, R. \& Capello, R. (1998). Towards Sustainable City Policy: An Economy-Environment Technology Nexus. Ecological Economics, 24(1), 103-118.

Castell, M. (1977). The Urban Question. Cambridge, MA, MIT Press.

Castells, M. (1978). City, Class and Power. New York, St. Martin's Press.

Chowdhury, A. \& Faruqui, S. (2009). Physical Growth of Dhaka City. Dhaka: Past, Present and Future. S. Ahmed. Dhaka, Asiatic Society.

Choudhury, B. \& Bell, G. (2011). The Engagement of Khan and Kahn in JSB. Architecture plus Design, 28(4), 104-111

Choudhury, B. \& Armstrong, P. (2012) Monuments and Architecture Shaping Bangladeshi Identity. Global Built Environmental Review, 8(3), 45-67.

Cooper, N. (2000). Urban Planning and Architecture in Colonial Indochaina. French Cultural Studies, 11(1), 7599.

Dani, A. H. (1962). A Record of its Changing Fortune. Dhaka, Asiatic Press.

Dovey, K. (1999). Framing places: Mediating Power in Built Form. London; New York, Routledge.

D'oyly, C. (1824). Antiquities of Dhaka. London, J.J.Landseer and Company.

File No-W-CAP-58/ACE. (1968). D. o. A. E. PWD). Dhaka, Department of Architecture (Erstwhile PWD).

Faludi, A. (2000). The Performance of Spatial planning. Planning Practice and Research, 15(4), 299-318.

Findley, L. (2005). Architecture, Politics and Cultural Agency. New York, Routledge.

Gable, R. W. (1967). Bureaucratic Transition: The Case of the British Colonies. Public Administration Review, 27(5), 474-482.

Geddins, A. (1979). Central Problems in Social Theory. Berkely, University of California Press.

Geddes, P. (1917). Report on Town Planning, Dacca. Calcutta, Bengal secreteriat Book Depot.

Gottdiener, M. (1985). The Social Production of Urban Space. Austin, University of Texas Press.

Harris, C. D. (1995). The Nature of Cities and Urban Geography in the Last Half Century. Urban Geography, 18, 15-35.

Hayder, Z. (1987). Organic Cities and the Case of Patric Geddes in Dhaka. Architecture. Massachusetts, Massachusetts Institute of Technology. Master of Science.

Hossain, S. (2008). Rapid Urban Growth and Poverty in Dhaka City. Bangladesh e-Journal of Sociology, 5(1), 124.

Hunter, W. W. (1976). A Statistical account of Bengal: Dhaka. Dhaka, Trubner Co.

Jahan, R. (1972). Pakistan: Failure in National Integration. New York, Columbia University Press.

Jahan, R. (2005). Bangladesh Politics: Problems and Issues. University Press Limited.

Jacob, J. (1961). The Death and Life of Great American Cities. Harmondsworth, Penguin.

Ksiazek, S. W. (1993). Architectural Culture in the Fifties: Louis Kahn and the National Assembly Complex in Dhaka. The Journal of the Society of Architectural Historians, 52(4), 416-435.

Karim, A. (1964). Dacca-The Mughal Capital. Dhaka, Asiatic Society of East Pakistan.

Khan-Nayma, N. F. (2009). Spatial Logic of Morphological Transformation: A Paradigm of Planned-Unplanned Areas in Dhaka City. 7th International Space Syntex Symposium, Stockholm.

Kong, L. (2007). Cultural icons and Urban Development in Asia: Economic Imperitive, National Identity, and Global City Status. Political Geography, 26, 383-404.

Lang, J. T. (2005). Urban design: A Typology of Procedures and Products. Oxford, Architectural.

Lawrence, D. L. \& Low, S. M. (1990). The Built Environment and Spatial Form. Annual Review of Anthropology 19(ArticleType: research-article / Full publication date: 1990 / Copyright (c) 1990 Annual Reviews): 453-505.

Lefebvre, H. (1991). The Production of Space. Oxford, OX, UK; Cambridge, Mass., USA, Blackwell. 
Low, M. (2004). Cities as Space of Democracy. Spaces of Democracy. C. B. M. Low. London, Thousand Oaks, New Delhi, Sage Publications.

Lynch, K. (1972). What time is this place? Cambridge, MIT Press.

Macfarlane, M. A. S. A. (1959). Master Plan of Dhaka. Dhaka.

Mascarenhas, A. (1971). The Rape of Bangla Desh. Delhi: Vikas.

Milam, W. B. (2009). Bangladesh and Pakistan: Flirting with Failure in South Asia. New York, Columbia University Press.

Nilufer, F. (2004). Hidden Morphological Order in an Organic City. Protibesh, 9, 34-41.

http://www.buet.ac.bd/protibesh/admin/pdf/IX_2004_Author4_Issue\%201.pdf

Njoh, A. J. (2003). Planning in contemporary Africa: The State, Town planning, and Society in Cameroon. Aldershot, Hampshire, England; Burlington, VT, Ashgate.

Njoh, A. J. (2007). Planning power: Town Planning and Social Control in Colonial Africa. London; New York, UCL Press.

Rotenberg, R. (2001). Metropolitan and Transformation of Urban Space in Nineteenth Century Colonial Metropoles. American Anthropologist, 103(1), 7-15.

Sayyad, A. (1992). Forms of Domonance: Onthe Architecture and Urbanism of the Colonial Enterprise. Aldershot, Avebury.

Schendel, W. V. (2009). A History of Bangladesh. Cambridge, UK: Cambridge University Press

SENES Consultants Limited, T. C. I. L. (2007). Dhaka Metropolitan Development Plan Strategic Environmental Assessment. Dhaka, The World Bank Washington, DC.

Sassen, S. (2010). The City: Its Return as a Lens for Social Theory. City, Culture and Society, 1, 3-11.

Susser, I. (2002). The Castells Reader on Cities Social Theory. Oxford, Blackwell Publishers Inc.

Talbot, I. (1998). Pakistan: A Modern History. New York: Palgrave Macmillan.

Taylor, N. (1998). Urban Planning Theory since 1945. London, Sage.

Tonkiss, F. (2005). Space, The City and Social Theory: Social Relations and Urban Forms. Cambridge, Polity.

Vale, L.J. (2008). Architecture, Power, and National Identity. 2nd Ed. New Haven, CT: Yale University Press.

Wright, G. (1988). Urban Space and Cultural Setting. Journal of Architecture Education, 41(3), 10-14.

Wyly, E. K. (1999). Continuity and Change in the Restless Urban Landscape. Economic Geography, 75(4).

Zaman, M. \& Lau, S. (2000). City Expansion Policy versus Compact City Demand: The Case of Dhaka. Compact Cities. R. Mike Jenks. London and New York. 